\title{
Politikayı Deneyimleyen Bir Toplumsal Hareket Olarak Gezi Direnişi
}

\author{
Seval ÜNLÜ GÖK*
}

\section{Özet}

Gezi Direnişi, yirmi birinci yüzyılın başında gerçekleşen beklenmedik, şaşırtıcı ve özgün bir toplumsal mücadele olarak toplumsal hareketler tarihindeki yerini almış bulunuyor. Onun ne ifade ettiği ve nasıl tanımlanacağıysa siyasal iktidar tarafından olduğu kadar sosyal bilimciler ve bizzat eylemcilerin kendileri tarafından da tartışılmaktadır. Toplumsal hareketleri anlamlandırma ve tanımlama çabası onları salt talepleri ve somut etkileri üzerinden değerlendiren yaklaşımlara yol açar. Oysa Gezi Direnişi’nde kanıtlandığı gibi toplumsal hareketler, somut taleplerinin ötesinde mevcut eșitsizlikleri dönüştürücü bir potansiyele ve alternatif bir toplumsallık arayışına da sahiptir. Bu makalenin amacı, Gezi Direnişi’ni dile getirilen talepler ve somut etkilerin ötesinde, sahip olduğu dönüştürücü potansiyel ve özgün bir çoğulluk durumunun mümkün kıldığı politika deneyimi ekseninde değerlendirmektir.

Anahtar Kelimeler: Gezi Direnişi, politika, toplumsal hareketler, hak talebi, çoğulluk

\section{Gezi Resistance: A Movement Experimenting with Poitics}

\section{Abstract}

Gezi Resistance which occurred at the beginning of the twenty first century took place in the history of the social movements as an unexpected, surprising and authentic social struggle. Its significance and the way how to define it is still discussed by social scientists and activists themselves as well as the political power. The effort to interpret and define social movements causes approaches which evaluate them upon their pure claims and concrete effects. However, as it's proved by Gezi Resistance, social movements have also a transforming potential against

\footnotetext{
* İstanbul Üniversitesi Uluslararası İlişkiler Bölümü Doktora Öğrencisi ve Beykent Üniversitesi Araştırma Görevlisi. E-mail: sevalunlu@hotmail.fr
} 
existing inequalities and a search for an alternative sociality beyond their concrete demands. The purpose of this article is to evaluate Gezi Resistance within the frame of its transforming potential and experience of politics enabled by a distinctive plurality case rather than the expressed claims and concrete effects.

Keywords: Gezi Resistance, politics, social movements, right claims, plurality

\section{Giriş}

2000'li yılların başından itibaren tüm dünyayı saran bir toplumsal hareketler dalgası, SSCB’nin yıkılmasıyla zaferini ilan eden liberal ekonomik ve siyasal düzenin halklar nezdinde sorunsuz işlemediğinin sinyallerini vermektedir. Dünya gündemine ilk kez Seattleda 30 Kasım 1999'da Dünya Ticaret Örgütü’ne (DTÖ) karşı düzenlenen kitlesel protestoyla giren, kesin bir antikapitalist karakterle ve giderek artan bir şekilde çokuluslu, kıtalararası birliktelikler üzerinden yürümeleriyle tanımlanan eylemler (Martin, 2008: 5), farklı coğrafyalarda, farklı şekiller altında ortaya çıkmaya devam etmektedir. Ortadoğu, siyasal rejimlerin çehresini değiştiren isyan hareketlerinin yuvası olurken $\mathrm{ABD}$ ve Avrupa ise düzenin olağan akşında kırılmalar yaratan işgal eylemleriyle karşılaşmıştır. Son on bir yılını bir başına hükümet kurmayı başaran bir partinin iktidarı altında geçiren Türkiye ise dünyadaki bu toplumsal mücadeleler dalgasına 2013 yılının Haziran ayında, Gezi Direnişi’yle katılmıştır.

Türkiye siyasal tarihinde pek çok toplumsal olayın gerçekleştiği Taksim Meydanı’nın ve bu meydanın hemen yanında direnişe adına veren Gezi Parkı’nın, 2011 yılında İstanbul Büyükşehir Belediyesi’nin onayladığı Taksim Yayalaştırma Projesi ve Topçu Kışlası Projesi kapsamında dönüștürülmesi planlanmıştır. Proje, onaylandığından itibaren Gezi Parkı’nın yok edileceği, Taksim Meydanı’nın daralacağı ve artık gösteri meydanı olarak kullanılamayacağı gibi çeşitli kaygılarla eleştirilerin ve protestoların hedefinde olmuştur. Bu eleştiri ve protestoların varlığına rağmen Gezi Direnişi, beklenmedik bir şekilde başlamıştır. Proje kapsamında ağaçların yerinden sökülmeye başlaması üzerine parkta çadırlar kurarak nöbet tutan gruba polisin müdahale etmesi, Gezi Parkı’ndan tüm ülkeye yayılan bir eylemlilik zincirinin kıvılcımını ateşlemiştir. Gezi Parkı’nda doğan mücadeleye İstanbul'un başka semtlerinden olduğu kadar Türkiye’nin başka şehirlerinin meydan ve parklarından da destek gelmiş, çatışma ve mücadeleler böylece yayılmıştır. Fiziki olarak yürütülen eylemler kadar sosyal medya aracılığıyla sağlanan iletişim ağı da Gezi Direnişi’nin bir parçası olmuştur. Ayrıca mücadelenin yoğunlaştığı meydan ve parkların işgalinden vazgeçildiği noktada farklı parklarda düzenlenen forumlar ve bireysel olarak gerçekleştirilen Duran Adam eylemleri de Gezi Direnişi’nin devamını sağlamıştır. Bu nedenle Gezi Direnişi dediğimizde Gezi Parkı’nda başlayıp tüm ülkeye yayılan, hem fiziki mücadele hem sosyal medya mücadeleleriyle şekillenen, topluca gerçekleştirilen işgal eylemleri kadar bölünerek gerçekleştirilen forumları ve çeşitli bireysel protesto biçimlerini de kapsayan eylemlilik sürecinin tamamını kastetmekteyiz. 
Gezi Direnişi, bir mücadele alanı olduğu kadar toplumsal hareketler araştırmacılarının dikkatlerini üzerine çeken sosyolojik bir saha da oluşturmuştur. Bir sosyolojik gözlem sahası olarak Gezi Direnişi, içinde yeşerdiği verili sosyo-ekonomik ve siyasal koşullar altında toplumsal yapıya somut etkileri itibariyle analiz edilmektedir. Ancak bu sosyolojik analize Gezi Direnişi’nin gerçekleşmemiş potansiyeli ve görünür olmayan boyutlarını da açığa çıkaracak bir bakışın eşlik etmesi gerekir. Keza toplumsal hareketlerin olağan gidişatı etkileme, değiştirme, dönüştürme gücüne sahip, olağan olmayan eylemlilikler olduğu hatırlanmalıdır. Y. Doğan Çetinkayảnın da (2008: 32) belirttiği gibi toplumsal hareketlerin en önemli özellikleri; engelleme, şok etme, şaşkına çevirme ve belirsiz, müphem haller yaratma güçleridir.

Toplumsal hareketleri bu olağan dışı, şaşırtıcı yönüyle ve somut etkilerden öte, dönüştürücü potansiyeliyle ele almak konusunda tüm toplumsal hareketler yazınının hemfikir olduğu söylenemez. Elbette, toplumsal hareketleri farklı bakış açllarıyla ele alan kuramlar, toplumsal deneyimlerin açığa çıkardı̆̆ı yeni sonuçlarla şekillenmiştir. Ancak, toplumsal hareketler araştırmalarının tarihine baktığımızda, bu alandaki yazının bir yandan kendinden önceki yaklaşımları eleştirerek ya da onlara yeni boyutlar ekleyerek geliştiğini, öte yandan toplumsal mücadelelerin dönüştürücü potansiyellerini silikleştirme ve onları sıradanlaştırma eğilimi kazandığını görürüz. Bu eğilimin ilk örneği sayılabilecek sosyal psikolojik yaklaşım ${ }^{1}$, yirminci yüzyılın başından ortalarına kadar toplumsal hareketler yazınına hâkim olmuş ve 1960'lı yıllarda yerini kolektif eylemi rasyonel motivasyonlarla açıklamaya yönelen araştırmalara bırakmıştır. ${ }^{2}$ Rasyonel örgüt yapısına vurgu yapan Kaynak Mobilizasyonu Teorisi ${ }^{3}$ ya da hareketlerin ortaya çıktığı politik boyuta odaklanan Politik Süreç ${ }^{4}$ yaklaşımı da rasyonellik vurgusunu sürdürmüş ancak toplumsal hareketlerin giderek normal ve sıradan toplumsal gelişmeler olarak görülmesine zemin sağlamıştır. 1970'li yıllarda hız kazanan çevre, kadın, barış, öğrenci ve eşcinsel hareketi gibi işçi mücadelesi dışında yer alan hareketleri inceleyen Yeni Toplumsal Hareketler yazını ${ }^{5}$, analiz nesnesi olan hareketleri tam da bu dönüştürücü ve muhalif güce sahip olmamalarıyla, sivil toplum içinde gerçekleştirilmesi beklenen sınırlı hedeflerle tanımlar. Toplumsal hareketleri sıradanlık ve rutinin içinde gerçekleşme şeklinde okuyan bir diğer yaklaşım da Jasper’in (2002) savunduğu, eylemlerin ardındaki yapılara odaklanmak yerine duygusal motivasyonları aramaya yönelen yaklaşımdır. ${ }^{6}$ Her biri toplumsal hareketler yazınının gelişmesine kaynaklık etmiş bu kuramlar mücadelelerin somut etkilerini farklı yönleriyle açıllarken, yeterince görünür olmayan ve potansiyel olarak var olan yönlerini ihmal etmişlerdir.

${ }^{1}$ Gustave Le Bon, 1895 ’te ilk kez yayımlanan sosyal psikoloji alanındaki Kitleler Psikolojisi (Psychologie des foules) adlı eserinde kolektif eylemi, aşırılıkla ve irrasyonellikle tanımladığı kitlelerin herhangi bir öneriye salgın gibi yayılan bir şekilde kanmalarıyla açıklar (Le Bon, 1971).

2 Olson, kolektif eylemin merkezine kâr-zarar hesabı yapan rasyonel bireyi koyarak toplumsal hareketlerde sosyal psikolojik yaklaşımın hâkimiyetine son vermiştir (Olson, 1971).

3 Kaynak Mobilizasyonu Teorisi için bkz. McCarthy ve Zald (1977: 1212-1241).

${ }^{4}$ Bir toplumsal hareketin ortaya çıkışında siyasal sistem içindeki olanaklara, çatışma ve ittifaklara odaklanan Politik Süreç yaklaşımı için bkz. Tilly (1978).

${ }^{5}$ Yeni Toplumsal Hareketler için bkz. Touraine (1978).

${ }^{6}$ Kolektif eylemde bireylerin seçimlerine ve duygularına eğilen bu yaklaşım için bkz. Jasper, (2002). 
Toplumsal hareketleri sıradanlaştırıcı bir bakış açısıyla değerlendirmekten kaçınmak adına, bu yazıda Gezi Direnişi hem sosyolojik boyutuyla hem de salt olgusal olanla açıklayamayacağımız ama direnişten yola çıkarak izleyeceğimiz politika kuramı eşliğinde düşünebileceğimiz politik boyutuyla ele alınacaktır. Bu politik boyutun ne olduğu, Rancière ve Arendt'in farklı politika anlayışlarının işaret ettiği ortak noktalar ve gerilimlerden hareketle anlaşılabilir. Politika, Rancière’in de (1992: 58) işaret ettiği üzere toplulukların kabulünün ve rızasının, iktidarların örgütlenişinin, konum ve işlevlerin dağıtımının ve tüm bunların meşrulaştırılmasının gerçekleştiği hükümet etme sürecinden başka bir süreci ifade eder. Hükümet etmeye ilişkin bu süreci Rancière (Rancière: 58) polis (police) ${ }^{7}$ olarak adlandırır ve bunun karşısında eşitlik adını verdiği başka bir süreci tanımlar. Bu tanıma göre eşitlik, polis düzeninden kaynaklanan eşitsizlikler karşısında eşitlik varsayımını gerçekleştiren eylemlerden oluşan, eşitsizliklerden özgürleşme (emancipation) sürecidir (Rancière, 1992: 59). Rancière (1995: 37) için politika ancak bu iki sürecin uyuşmazlık (dissensus) içinde karşılaştığı, eşitlik sürecinin doğal kabul edilen polis düzenini sekteye uğrattığı zamanlarda, ender ve kısa süreli olarak ortaya çıkar. ${ }^{8}$ Benzer şekilde Arendt (1990: 273) modern devrimlerde ancak kısa süre ayakta kalabilen konsey deneyimlerini, eylemin ve katılımın zemini olarak işaret eder. Bununla birlikte politikanın sadece bu kısa devrim anlarına özgü olduğunu düşünmez. Politikayı insanlık koşulunun sağladığı konuşma ve eyleme kapasitesiyle ilişkilendirir (Arendt, 1998). Arendt'in eşitlik anlayışı, kapasite eşitliği olarak tüm insanları kapsar. Bu iki düşünürün politika kuramları arasındaki gerilim, eşitlik anlayışlarının farklılığından ileri gelir. Rancière, somut eşitsizliklerden hareket edip politikayı kısa süreli anlara hapsederken Arendt, ortak bir dünyayı paylaşmamızdan ötürü politikayı sürekli var olması mümkün bir toplumsal ilişki biçimi olarak düşünür ama kuramını somut eşitsizliklerle ilişkilendirmez.

Birbirinden farklı politika anlayışları olan bu iki düşünürün bize işaret ettiği ortak nokta, politik olanın dar kurumsal anlamının ötesinde ve mevcut siyasal mekanizmaların işleyişi dışında araştırılması gerekliliğidir. Gezi Direnişi, karşısındakileri bocalatan ve şeylerin olă̆an akışı'nda ${ }^{9}$ kırılma yaratan bir toplumsal hareket olmanın yanında, bize politikanın ne olduğuna dair ipuçları veren bir zemindir. Buradan hareketle, öncelikle Gezi Direnişi’nde amaç ve taleplerin dile getirilme süreci incelendikten sonra, bu direnişin hangi özellikleri itibariyle politik olduğu tartışılacaktır.

\section{Gezi Direnişi: Amacını Arayan Bir Toplumsal Hareket}

Tüm toplumsal mücadelelerde olduğu gibi Gezi Direnişi’nde de şu soru tartışmaların merkezine oturmuştur: “Talepleriniz neler?” Bu soru, hükümet yetkililerinden medya mensuplarına ve bu

\footnotetext{
7 Rancière, toplulukların kabul edilip onaylandığı ve onaylarını verdiği, iktidarların örgütlendiği, yerlerin ve görevlerin dağıtıldığı ve bu dağıtımın meşrulaştırıldığı sistemin içinde gerçekleștiği, genellikle politika dediğimiz bu sürece police demeyi önerir. Geniş anlamıyla police; rollerin dağıtıldığı, adların ve görevlerin pay edildiği, neyin görünür ve söylenir olduğunun belirlendiği, konuşmaya kadir olanlar ve olmayanların, sözü bir söylem olarak ya da gürültü olarak duyulanların eşitsiz paylarının gerçekleştiği düzeni ifade eder (Rancière, 1995: 51-53).

${ }^{8}$ Rancière, police düzeninin temelinde consensus (uzlaşı) bulunduğunu belirtir. Politika, bu consensus düzeninde kırılmayı sağlayan, police düzeninden doğan eşitsizliğe karşı eşitliği onaylamak üzere girişilen eylemdir. Rancière, politikanın yarattığı bu durumu consensus ile zıtlığı içinde tanımlamak üzere dissensus kavramını üretmiştir (Rancière 1995: 51-53).

9 Bu kullanıma başvurulurken Rancière’in (2012: 8) "le cours normal des choses" ifadesinden esinlenilmiştir.
} 
alanla ilgilenen sosyal bilimcilere kadar herkesin Gezi Direnişi’ni anlama ve tanımlama çabasının simgesidir. Keza yurttaşlar, seçim ya da yerel meclisler gibi mevcut siyasal mekanizmalar aracılı̆̆ıyla değil de kendiliğinden ve beklenmedik toplumsal bir patlamayla harekete geçmişse ancak birtakım acil taleplerine yanıt arıyor olmalıdırlar. Öyleyse eylemcilere düşen taleplerini net şekilde ifade etmek, yetkililere düşense bu taleplere yanıt vermektir. Gezi Direnişinini söz konusu talep-yanıt döngüsü dışında ve politik boyutuyla değerlendirmek için öncelikle toplumsal hareketler ve hak talepleri arasındaki ilişkiyi, ardından Gezi Direnişi’ne hak talepleri üzerinden getirilen tanımları incelemek gerekmektedir.

\section{Toplumsal Hareketler ve Hak Talepleri}

Toplumsal hareketler modern devrimlerden bu yana toplumlardan hiç eksik olmamıştır. Kapitalizmin gelişimine paralel olarak siyasal liberal ideoloji ekseninde anayasal rejimler kurulurken, hâkim olan biçimsel eşitlik anlayışının dışında kalanlar, mücadeleleriyle toplumsal ve siyasal yapılar üzerinde dönüştürücü etkiler yaratmıştır. İçinde yeşerdikleri toplumsal ve siyasal yapıları dönüştürürken toplumsal hareketlerin kendisi de dönüşümlere uğramıştır. Birbirini dönüştüren bu karşılıklı ilişki, on dokuzuncu yüzyıl toplumsal mücadeleleri ve bu mücadelelerin gerçekleştiği toplumsal koşullarda egemen olan liberal ideoloji arasında son derece güçlüdür. Beetham (1994: 56), on dokuzuncu ve yirminci yüzyll boyunca liberalizmin hem demokrasi için gerekli zemini oluşturduğunu hem de demokrasiyi sınırlandırdığını belirterek bu gerilimli ilişkiyi vurgulamıştır. Öyle ki, tüm kurumlarıyla, araçlarıyla ve mekanizmalarıyla siyasal rejimlere yön veren liberal demokrasi, bugün bildiğimiz şeklini uzun toplumsal mücadeleler sonunda almıştır.

Toplumsal hareketleri siyasal liberalizmle olan ilişkisi çerçevesinde sağlayan temel unsur, bu ideolojinin biçimsel bir eşitlik anlayışının olmasının yanı sıra eşitsiz şekilde yoksun bırakılan hakların varlığından doğan mücadele alanın var olmasıdır. Gambetti’nin de (2009: 152) işaret ettiği gibi birçok özgürlük mücadelesi liberal demokrasinin açtı̆̆ı alanda yeşermiştir. Siyasalliberalizmin eşitsizliklerinden doğan mücadele alanını örnekleyen başlıca toplumsal hareketlerden biri oy hakkı mücadeleleridir. Avrupada ulus devletlerin yükselmesine paralel olarak yurttaşılı kurumu doğarken, oy hakkı ancak dar bir kesime tanınmıştır. Sınıf, cinsiyet, etnik köken kıstaslarına göre bu haktan yoksun bırakılan mülksüz erkekler, kadınlar ve siyahlar bu eşitsizlikleri ortadan kaldırmak için uzun mücadeleler vermişlerdir. Dışlama stratejilerine karşı genel oy hakkı için yürütülen bu toplumsal mücadeleler, liberal demokratik kurumların gelişmesi ve oy hakkının genişlemesi ile sonuçlanmıştır. Therborn (1989: 64) siyasal liberalizmdeki bu dönüşüme, klasik liberallerin kapitalizmle demokrasinin bağdaşmazlı̆̆ına sarsılmaz bir inanç beslerken çağdaş liberallerin kapitalizmle ancak ve ancak demokrasinin bağdaştığını savunduklarını söyleyerek dikkat çekmektedir.

Oy hakkı mücadelelerinde olduğu gibi toplumdaki somut eşitsizliklere itiraz edenler siyasal iktidarı kimi taleplere yanıt vermeye zorlamıştır. Siyasal liberalizmin ilkesel düzeydeki eşitliğini, somut eşitsizlikler karşısında talep edenler kazanımlar elde ederken, liberalizmi ve kurumlarını da dönüştürmüştür. Bu mücadeleler toplumsal hareketlere önemli bir miras birakırken, siyasal 
iktidarların da toplumsal hareketler karşısında deneyim kazanmasını sağlamıştır. Maruz kalınan eşitsizliklere karşı yürütülen mücadeleler, kazandıkları hakların ötesinde toplumdaki tüm tahakküm ve sömürü ilişkilerini dönüştürmeye yönelik istek ve potansiyeli de içinde barındırmıştır. Ancak, toplumsal hareketler karşısında giderek deneyim kazanan siyasal iktidarlar, mücadelelerin bu dönüştürücü potansiyelleri karşısında onları salt somut hak talepleri olarak tanımıștır. Uzun mücadeleler sonunda kazanılan haklar, itirazları değerlendiren ve onlara yanıt veren merci olarak siyasal iktidarın konumunu da güçlendiren bir etki meydana getirmiştir. Gambetti (2009: 151-152), politikayı hükümet etmeye, demokrasiyi de yönetim teknikleri bütününe indirgeyen liberalizmde, talep siyasetiyle talep edenin değil, talebi duyması istenen iktidarın belirleyici konuma konulduğunun zımni olarak kabul edildiğini belirtir. Böylelikle toplumsal hareketler, bugün de görmeye alışı olduğumuz şekilde, talep edenler ve kendisinden talep edilenler şeklindeki siyasal hiyerarşik bir çerçeveye sıkıştırılmaktadır. Siyasal iktidarlar, yerleşik eşitsiz toplumsal ilişkileri dönüştürücü güce sahip hareketleri salt hak talepleri olarak değerlendirerek talep eden ve talebi değerlendiren, yöneten ve yönetilen ya da halk ve iktidar arasındaki eşitsiz ilişkiyi yeniden üretmektedir. Amaç, eşitsiz bir şekilde yoksun kalınan hakkı kazanmak olarak okunursa bu kazanım ancak siyasal iktidarın kara kutusundan geçerek gerçekleşecektir. ${ }^{10}$

Toplumsal hareketleri hak talebi sınırları içinde algılama refleksi Gezi Direnişi'nde de kendini göstermiş̧ir. Siyasal iktidarın Gezi Direnişi’ni ne şekilde ve hangi motivasyonlarla hak talebi olarak algıladığını değerlendirmeden önce şu sorulara yanıt aramamız gerekmektedir: Gezi Direnişi hangi hakkı ya da hakları siyasal iktidardan talep etmiştir? Direnişin amacıyla ve talepleriyle, eylemci bileşenleri, eylem repertuar ${ }^{11}$ ve örgütlenme biçimi arasında nasıl bir ilişki vardır?

Gezi Direnişỉnde hak talebiyle ifade edilmiş bir amaç, bu amaç etrafında bir araya gelmiş eylemci bileşenler, bu amaca bağlı bir eylem repertuarı ve örgütlenme biçimi aradığımızda kendi içinde belirsizlikler ve çelişkiler barındıran bir toplumsal hareketle karşılaşırız. Öncelikle harekette net bir amaçtan çok bir belirsizlik durumu hâkim olmuştur. Bir bütün olarak Gezi Direnişi, hareketin kıvılcımını ateşleyen parktaki ağaçların korunması amacını aşmış, daha çok sürecin kendi içinde karşılaşılan saldırı ve engellemeler sonucu ortaya çıkan kısa vadeli hedeflerle yönlenmiştir. Eylemci bileşenlerine baktığımızda kazanılacak bir hakkın müstakbel sahibi olan homojen bir özneden çok, bu hareketin bir parçası olmalarından önce ortak bir paydada tanımlanamayacak kadar heterojen bileşenlerle karşılaşırız. Feministler, LGBT’ler, çevreciler ve Anti-Kapitalist Müslümanlar gibi farklı alanlarda mücadele yürüten muhalif

10 Easton (1965), sistemik modelinde siyasal sistemi çevreden kendisine yöneltilen talepleri girdiler olarak kabul edip, onları çıtıllara çevirerek yine çevreye salan bir kara kutu olarak görür. Easton’un siyasal sistem analizi, toplumsal hareketleri hak taleplerinden öte görmeyen mevcut siyasal mekanizmaların işleyişini açıklamaktadır. Ancak bu yazıda toplumsal hareketlerin siyasal sistemin girdileri ve çıktıları arasındaki bu döngüsel işleyişini kırma potansiyelleri savunulmaktadır.

11 Toplumsal hareketler yazınına Tilly’nin kazandırdığı eylem repertuarı kavramı, eylemlilik sırasında eylemcilerin kullanabilecekleri sınırlı eylem biçimlerinin tümünü ifade eder. Toplumsal hareketleri tarihsel bir bakış açısıyla ele alan Tilly, geleneksel ve modern toplumsal hareketlerin farklı eylem biçimlerine sahip olduğunu açıklarken eylem repertuarı kavramına başvurur. Tilly’nin Fransa'da on yedinci yüzyıldan günümüze dek değişen eylem repertuarını anlattığı eseri için bkz. Tilly (1986). 
gruplar, örgütlü sol grup ve partiler, muhalefet partileri, meslek grupları, sendikalar, taraftar grupları, öğrenciler ve bu tanımların içinde yer almayan bireysel katılımcılardan oluşan bu liste genişletilip detaylandırılabilir. Bu çeşitlilik, Gezi Direnişi’ndeki özgün deneyime olanak veren unsurların başında gelmektedir. Bu heterojen bileşenlerin benimsediği eylem biçimleri de kendi içinde birbiriyle çatsşan bir eylem repertuarı sunar. Keza polis müdahaleleri karşısında nasıl bir yol izleneceği eylemcileri karşı karşıya getiren önemli bir sorun olmuştur. Örgütlenme biçimi açısından ise tam bir doğaçlama söz konusudur. Meydanlar ve parklar doğaçlama gelişen bu bir araya gelişin somut mekânları olurken iletişim ağının en temel unsuru sosyal medya olmuştur.

Gezi Direnişi bu özgün haliyle hak talebi etrafında örgütlenerek gerçekleştirilmiş bir toplumsal hareket görüntüsü çizmemektedir. Benlisoy’un (2013: 124) vurguladığ gibi Gezi Direnişi, bir toplumsal hareketin ya da siyasal bir mücadelenin mantıksal sonucu ya da evrimsel gelişiminin ürünü değil, bir kırılmadır. Yine de Gezi Direnişi’nde hiçbir talebin dile getirilmediği söylenemez. Gezi Direnişini temsilen Taksim Platformu, siyasal iktidarla yapacağı ilk görüşmeye taleplerini kaleme alarak gitmiş ve böylelikle Gezi Direnişi kendisini siyasal iktidara anlatabilmek üzere sıraladığı maddeleri "talep ediyoruz" şeklinde noktalayan bir metinle, taleplerini ilk kez dile getirmiştir (BBC, 2013). ${ }^{12}$ Bu metinde Gezi Direnişinnin doğduğu yer olan Gezi Parkı ve Taksim’e yönelik özel talepler bulunduğu gibi, ifade özgürlügüyle ilgili genel talepler ile eylemlilik içinde gerçekleşen ölüm ve yaralanmaların sorumlularının görevden alınması ve eyleme katıldığı için gözaltına alınanların serbest bırakılması gibi sürece ilişkin talepler yer almıștır. Onu ortaya çıkaran ilk nedeni aşan bu hareket, dile getirilen bu taleplerle de tanımlanmakta ve kendini tanımlamakta zorlanmıştır. Çünkü Gezi Direnişìnde net bir talepten çok farklı taleplerin doğaçlama bir şekilde dile getirilişi söz konusu olmuştur.

Gezi Direnişi süresince dile getirilen hiçbir talep bu toplumsal hareketi bir başına açıklamak konusunda yeterli değildir. Bu hareket Gezi Parkı’nı koruma hareketi midir? İstanbullular olarak şehirle ilgili kararlarda söz sahibi olma mücadelesi midir? Bir ekoloji hareketi mi yoksa on bir yıllık AKP iktidarına karşı bir isyan hareketi midir? Taleplerini aşan ve başta hükümet olmak üzere kamuoyunu şaşırtan bu hareketi tanımlama arayışı tüm eylemlilik sürecine eşlik etmiştir. Çünkü siyasal iktidarlar açısından seçim döngüsünün büyük ölçüde sağladığı öngörülebilirliği bozan, şaşırtan ve bocalatan bir toplumsal hareketin gücü son derece tehlikelidir. Keza Gezi Direnişi süresince sıkça seçim sandığının işaret edilmesi de öngörülemezliğin yarattı̆̆ı bu kaygıyla ilgilidir. Öyleyse bu toplumsal hareket "makul” sınırlar dâhilinde, bir şekilde tanımlanmalıdır.

\section{Gezi Direnişi'ne Getirilen Tanımlar}

Bir toplumsal olguyu tanımlamak neyle karşı karşıya olduğunu bilmek ve onu bilinenler kategorisine almak demektir. Burada bilmek, her ne kadar anlama ve kavramayı çağrıştırıyorsa da söz konusu olan değişmez ve mutlak bir gerçekliği anlamaktan çok oluş halindeki ve

12 Bu görüşme 5 Haziran 2013 tarihinde Başbakan Vekili Bülent Arınç ve Taksim Platformu’nu temsilen altı üyenin katılımıyla gerçekleşmiştir. Taleplerin iletildiği metni görmek için bkz. BBC (2013). 
yanlışlanabilir bir gerçekliği anlamlandırma çabasıdır. Öyleyse tanım, olguya atfedilen anlamla şekillenir. Atfedilen anlamla birlikte getirilen tanım, bu toplumsal olguya karşı nasıl bir tutum alınacağının belirlenmesinin de ön koşuludur.

Bu bağlamda, beklenmedik gelişmesiyle karşısındakini şaşırtan, bocalatan bir hareket olarak Gezi Direnişi’ne iktidar tarafından getirilen çeşitli tanımlamalar, direnişe atfedilen anlamlarla ilişkilidir. Gezi Direnişi küçümsendiğinde 'çapulculuk'; illegal örgütlerin tahrik edici bir oyunu olarak anlamlandırıldığında 'marjinallik'; hükümete karşı gizli güçlerin bir oyunu olarak düşünüldüğünde ise 'faiz lobisi'nin 'büyük oyunu' olarak tanımlanmıştır. ${ }^{13} \mathrm{Bu}$ tanımlamalarda hâkim olan görüş, Gezi Direnişi’nin göründüğünden öte anlamlar taşıdığı şeklindedir. Bu nedenle Gezi Direnişi’nin "birkaç ağaç", "çevre duyarlılı̆̆ı", "park meselesi” olmayıp bu görüntünün ardında terörle, güvenlikle ilişkilendirilen başka amaçlar olduğu belirtilmiştir. Ancak, müdahaleler karşısında sönümlenmek yerine geliştikçe, yayıldıkça, renklendikçe ve şaşırtmaya devam ettikçe, Gezi Direnişinnin göründügünden başka ve fazla olan anlamları iktidar açısından daha büyük bir tehlike haline gelmiştir. Çünkü iktidar algılayamadığı, tanımlayamadığı ve tüm baskısına rağmen kontrol altına alamadığı bir muhalefet biçimiyle karşs karşıya kalmıştır. Rancière'in terimleriyle ifade edersek Gezi Direnişỉnde uyuşmazlık durumu ortaya çımıştır. Mevcut politik mekanizmalar ve bu mekanizmaları ellerinde bulunduranların onayladığı toplumsal düzenle anlaşmazlık içine girilmiş ve bu toplumsal düzenin uzlaşmacı (consensuel) mantığında bir kırılma sağlanmıştır. Bu kırılmada, iktidarın meşruluğu yok olmuştur. Direnişe karşı "ne istediniz de yapılmadı?” şeklindeki paternalist yaklaşım, siyasal iktidarın Gezi Direnişinin motivasyonlarını anlayamadığının samimi bir itirafıdır. ${ }^{14}$ İktidarın olup biteni kavrayamadığını ve anlayamadığını göstermiş̧ir; ancak iktidar için temel sorunun anlamak değil durdurmak olduğu da açıktır. Öyleyse bu dissensus bir şekilde consensus'e çevrilmelidir.

Böylelikle hareketi tepkisel olarak tanımlamak yerine onu makul bir anlamla donatacak biçimde stratejik olarak tanımlamak, iktidarın Gezi Direnişiyle mücadele yollarından birine dönüşmüştür. Yok sayma ve karalama söylemlerine, merkez medyanın sansürüne ve polisin şiddetli müdahalesine rağmen devam eden Gezi Direnişỉni anlamlandırmaya çalışmak yerine, direnişin getirilen tanıma göre şekillendirilmesi amaçlanmıştır. Başta böyle bir direnişi önemsemediğini, bunun üstesinden nasıl geleceğini bildiğini kanıtlamaya çalışan tanımlamalar yerini hareketin kendisine yön verecek bir tanım arayışına bırakmıştır. Başka bir deyişle, olguya atfedilen anlamla şekillenen tanım bu kez anlamı şekillendirmek üzere devreye sokulmuştur. Bu aşama aynı zamanda iktidarın geldiği en uzlaşmacı noktayı da işaret eder. İstanbul Büyükşehir Belediye Başkanı, 8 Haziran günü yaptığı açıklamada Gezi Parkı için AVM, otel veya rezidans

13 Yazmacı (2013), hükümetin Gezi Direnişi’nin ardındaki gizli güçler olarak Yahudileri ve faiz lobisini işaret etmesinde, siyasal ve toplumsal tahayyülde köklü șekilde yer etmiş bulunan komplo kültürünün etkisine dikkat çekmektedir. Komplo teorilerini, siyasal iktidarların toplumsal olayların sosyolojik kökenlerini anlamak yerine gerçeklerden kaçış ve siyaseten hayatta kalma stratejilerinin bir parçası olarak değerlendiren bu çalışma hakkında daha ayrıntılı bilgi için bkz: Ümit Yazmacı (2013: 153-180).

14 Başbakan Recep Tayyip Erdoğan’ın 1 Haziran 2013’te Türkiye İhracatçılar Meclisi Genel Kurulu’nda yaptığı konuşmada "Bir başbakan olarak soruyorum, benim muhatabım kim? Benim muhatabımın bir samimiyeti, dürüstlüğü varsa, çıksın ortaya ne talep ettiğini söylesin” şeklindeki sözleri, Direniş’te olanların anlamlandırılamadığının ama talepler netleşirse bir anlam verilebileceğinin ifadesidir (Anadolu Ajansı, 2013). 
projelerinden vazgeçildiğini, projenin müzakere edilerek şekilleneceğini, her durumda yeşil bir çevre düzenlemesi yapılacağını belirtmiştir (Sabah, 2013). Bir iktidar yetkilisi tarafından yok sayıcı ve karalayıcı ifadelerin bulunmadığı bu ilk kapsamlı açıklamada iktidarın Gezi Direnişine yönelik tanımlarından çıkarsadığımız tutumunda stratejik bir yönelimin ipuçları bulunmaktadır. Öncelikle bu açıklamanın bir hükümet yetkilisi tarafından değil de İstanbul Büyükşehir Belediye Başkanı tarafından yapılması, direnişin sadece İstanbul ile hatta Gezi Parkı’yla ilgili kısmının konuşulmasını sağlamıştır. Açıklamada, Gezi Direnişi’nin tretuvar genişletme çalışmasını Topçu Kışlası inşaatı sanan ağaç severlerin çevre duyarlılığından doğduğu belirtilmiştir. Buna ek olarak Topbaş, Taksim Platformu’nun kendileri adına konuşan marjinallerden ve siyasilerden rahatsızlık duyduğunu ve bunları kabul etmediğini söyleyerek tanımına meşru bir dayanak sağlamıştır: Gezi Parkı parkta çevre duyarlılığına sahip vatandaşların parklarına ve ağaçlarına sahip çıkma, kentleriyle ilgili söz söyleme mücadelelerinin hareketidir. Bu tanımlamadaki stratejik yönelim öncelikle tüm ülkeye yayılmış direnişi, onun doğduğu yer olan Gezi Parkı'na hapsetmek arayışındadır. İkinci olarak Gezi Direnişinnin çok çeşitli bileşenleri salt çevre duyarlılı̆̆ıyla hareket eden kişilere indirgenerek direniş içindeki farklı yönelimler ötekileştirilmeye çalışılmıştır. Son olarak da direniş, iktidarın yönetebileceği bir çizgiye çekilmek üzere yaşadığı kentle ilgili söz sahibi olma hakkının talebi olarak konumlandırılmış ve bu talebin de karşılanacağı belirtilerek fazla büyümüş olan bu hareketin hak kazanımıyla sonlandırılması istenmiştir. Direnişin bir hak talebi olarak tanımlanması, vatandaşların şehirle ilgili kararlarda katılımcı olma isteklerinin açığa çıkması olarak anlamlandırılmasından ötürü değildir. Bu tanımla iktidar, talep eden ve kendisinden bu talebi duyması istenen arasındaki hiyerarşik ilişkiyi yeniden üretirken, mevcut konumların ve eşitsizliklerin sorgulandığı bir toplumsal hareketten dönüştürücü gücünü söküp almayı hedeflemiştir. İktidar yetkililerinin eylemcilere "çevre duyarlılı̆ııla hareket eden gençler" diye seslenmesi, Direnişi talep siyasetinin olanak sağladığı "makul" bir tanım içinde tutma arayışlarını kanıtlamaktadır.

Gezi Direnişi’nin bu tanıma hapsolmasında merkez medyanın katkıları büyüktür. Sansürden vazgeçtiği andan beri merkez medya direnişi tek bir yönüyle; eylemcilerin polise yiyecek ikram ettiği, karşıt gruptan eylemcilerin birbirinin elinden tuttuğu, insan zinciriyle çöplerin elden ele taşındığı, şiddete karşı oluşun vurgulandığı, makul olduğu ölçüde yayınlanan mizahi yönüyle lanse etmiştir. Çevreci, iyi niyetli, barışçl ve polise karşı koymayan her görüntü Gezi Direnişi’nin gerçek yüzü, bu kalıba uymayanlar ise hareketin içine sızmış ideolojik, politik ve art niyetli görüntüler olarak paylaşılmıştır. Direniş noktalarından yapılan canlı bağlantılarda konuşan eylemci sanatçılar barışçıl duyarlılık mesajlarını iletip hoşgörü talebinde bulunmuşlardır. Eylemcilere mikrofonlar uzatıldığında kim oldukları ve ne istedikleri sorulmuştur. Geç gelen bu ilgi, hareketi en iyi eylemcilerin tanımlayabileceğine dair inancı yansıtmaktadır. Ne var ki, "Neden buradasınız?" sorusu son derece yönlendirici bir sorudur; özellikle de söz konusu olan bir toplumsal mücadeleyse. Eylemcilere kendini ifade etme şansı tanıan bu soru, onları ne istediğini bilen, kendine güvenli bir yanıta zorlamıştır.

İlk kez karşılaşılan eylemcilerin profilini çıkarmak için gerçekleştirilen sosyolojik araştırmalar da eylemin kendisine yönelmesine ve Gezi Direnişi’nin kendi kendini tanımlamasına zemin hazırlamıştır. İstanbul Bilgi Üniversitesi’nin eylemlilik sürerken gerçekleştirdiği anket eylemcilerin 
kimliğini ve taleplerini ortaya koymayı amaçlamıştır. Ankete göre büyük çoğunluğu kendini özgürlükçü olarak tanımlayan eylemcilerin direnişe katılma nedenlerinin başında başbakanın otoriter tavrına ve polisin orantısız gücüne karşı çıkmak gelmektedir. ${ }^{15}$

Gezi Direnişi eylemcilerine yönelik çevre duyarlılı̆̆ına sahip gençler, yaşadığı şehirle ilgili kararlarda söz almak isteyen vatandaşlar, başbakanın otoriter tavrını eleştirenler gibi nitelemelerinin hepsi direnişi bir boyutuyla açlklamaktadır. Gerek iktidar ve medya, gerek sosyolojik anketler ve bizzat eylemcilerin kendileri harekete tanımlar getirmiştir. Bu yazıda amaç, bu tanımlamalardan daha doğru ve daha kapsayıcı bir tanımlama olduğunu ya da bu tanımlamanın en doğru şekilde birileri tarafından yapılabileceğini savunmak değildir. Sorun, her "kimsiniz ve ne istiyorsunuz?" sorusunun ardındaki uzlaşı arayışının nedenlerini anlamaktır. Sorun tüm tanımların sakladığı, sınırladığı, eksilttiği ve tükettiği boyutu açığa çıkarmaktır. $\mathrm{Bu}$ boyut, direnişin politik boyutudur. Her tanımda yitirilen; sınırsızlık, tamamlanmamışlık ve belirsizlikle kendini var eden politikanın ta kendisidir.

\section{Gezi Direnişi'nde Politikayı Mümkün Kılan Koşulların İpuçları}

Politikayı, hükümet etmeye ilişkin mevcut süreçler dışında ve kolektif eylemle ilişkisi içinde aradığımızda, onun ancak birtakım özgün koşullarda ortaya çıkabileceği açıktır. Gezi Direnişi’nde deneyimlendiğini savunduğumuz politika, en başta özgün bir çoğulluk durumunun ürünüdür. $\mathrm{Bu}$ çoğulluk durumu ise çarpışma, şaşırma ve üretme olarak adlandırdığımız süreçlerin yaşanmasına izin vermiştir.

\section{Çoğulluk ve Çoğulculuk}

Gezi Direnişỉndeki özgün deneyimi mümkün kılan koşulların başında eylemci bileşenlerin çeşitliliğinin geldiği vurgulanmıştı. Eylemci bileşenlerin bu çeşitliliği nadiren deneyimlenebilen bir çoğulluk durumu meydana getirmiştir. Günümüz hâkim demokrasi anlayışının vazgeçilmez değeri ve ögesi çoğulculuk (pluralisme) ile Gezi Direnişi’nde deneyimlenen çoğulluk (pluralité) durumunu birbirine karıştırmamak gerekir. Keza bu yazıda, günümüzün hâkim demokrasi anlayışının yücelttiği bir değer olan çoğulculuğun benimsediğiyle Gezi Direnişi’nde özgün bir şekilde gerçekleşen çoğulluğun birbirinden farklı anlayışların ürünü olduğu savunulacaktır. Başka bir deyişle Gezi Direnişi, söylem düzeyinde kalan bir değer olarak çoğulculuğun gerçekten uygulandığı bir yer değil, çoğulculuktan ne anlaşılacağı konusunda hâkim görüşle uyuşmazlık içinde olarak, bu kavramdan başka bir anlamın çıkartılabileceğinin kanıtlandığı yerdir.

Hannah Arendt'in demokrasi anlayışını tartışan Berktay'in (2012: 207) çoğulluk ve çoğulculuk kavramlarına ilişkin uyarısı Gezi Direnişi açısından dikkat çekicidir. Berktay (2012: 207), Arendt'in çoğulluk kavramının karşıt çıkar gruplarının rekabetine dayanan liberal çoğulcu

15 İstanbul Bilgi Üniversitesi’nin Gezi Direnişi süreci içinde gerçekleştiği anket için bkz. T24 (2013). 
anlayıştan, kimlik politikasının temel aldığı bütünlük idealinden, uzlaşmaz ve karşılaştırılamaz farklılıkların varlığ şseklindeki radikal çoğulculuk anlayıştan farklı olduğunu vurgular. Arendt’e göre ortak bir kimlik etrafında birleşilmesi değil, farklılıkların ortak bir hedef uğrunda birleşmesi sonucu oluşan kolektif politik eylem çoğulluk durumunu yaratır (aktaran Berktay, 2012: 209). Çoğulculuk ve çoğulluk kavramlarını birbirine yaklaştıran unsur ikisinin de farklı görüşlerin varlığıyla oluşmasıdır. İki kavramı birbirinden ayıransa farklı görüşlerin düşünsel sınırlarının uğradığı değişikliklerdir. Düşünsel sınırlar; bir görüşün yapısını ve çerçevesini belirleyen, ifade edilenin altında yatan, neyin nasıl bilinebileceğine dair kabullerin toplamılla belirlenir. Görüssler; olaylar ve olgular üzerine dile getirilen düşüncelerdir ama onlara yön veren bir yörünge dâhilinde var olurlar. Dolayısıyla düşünsel sınırlar; neyin, nasıl, ne ölçüde bilinebileceğinin haritası olarak ele alınmaktadır.

Çoğulculuk bugün siyasal mekanizmalardan medyaya birçok kurumun temel değerleri arasında bulunan bir prensiptir. Bu prensip, söylem düzeyinde olduğu kadar uygulama düzeyinde de varlık bulur. Çoğulculuk, farklı görüşlerin kendi rızalarıyla ve ortak bir amaç için belli bir zeminde bir araya gelmeleri olarak karşımıza çıar. Bu tabloyu ortaya çıarabilen zeminlerin daha demokratik olduğu vurgulanır. Siyasi partilerin kadrolarından sivil toplum örgütlerinin üyelerine kadar farklı görüşlerden insanların bir araya gelebilmiş olması bir demokratiklik ölçütü olarak kanıtlanmaya çalışılır. Bu çoğulculuk tablosunu en iyi örnekleyen zeminlerden biri televizyon ve radyo kanallarında yayınlanmak üzere düzenlenen tartışma programlarıdır. $\mathrm{Bu}$ programlara, tartışılacak konuya farklı açılardan yaklaşacağı bilinen katılımcılar davet edilir. Herhangi bir katılımcının bakış açısı hem moderatör hem de diğer katılımcılar tarafından zaten bilinmektedir. Programda önemli olan, zaten bilinen bu bakış açllarının sergilenmesidir. Tartışma, bu zeminde neredeyse hiç bulunmaz çünkü her katılımcı sadece kendi bakış açısını gündem konusu aracilgğıyla ortaya koymakla yükümlüdür. Dolayısıyla bu programlarda hâkim olan prensip uzlaşmadır. Kaldı ki fikirlerin birbiriyle en çok zıtlaştı̆̆ı, çatıştığı ve birbirini kabul etmediği noktada uzlaşı düzeninin sihirli sözcüğü "saygı" devreye girer. Birbirinin görüşlerine karşı argüman üretemedikleri noktada katılımcılar, karşısındakinin görüşlerine saygı duyduklarını belirtip sergilemek üzere geldikleri görüşlerine hiçbir şey eklemeden ya da ondan hiçbir şey kaybetmeden tartı̧mayı baştan sonlandırırlar. Bu nedenle çoğulculuk, tartışma programlarında sergilendiği gibi, farklı görüşlerin hiçbir değişime uğramaksızın bir araya geldiği zeminlerdir. Başka deyişle hâkim çoğulculuk anlayışı düşünsel sınırların yerinden oynamadığı, uzlaşmaya dayalı bir birliktelik halidir. Uzlaşma, tartışmanın nesnesi üzerine değil, mevcut sınırların değişmemesi üzerinedir. Öyleyse liberal demokrasinin bir değer olarak benimsediği ve benimsediği şekliyle de uyguladığı çoğulculuk ancak bu belli sınırlar içinde kalınarak gerçekleştirilir.

Gezi Direnişỉnde çoğulculuktan, farklı görüşlerin düşünsel sınırlarının değişmediği, uzlaşı içindeki bir birliktelik halinden daha farklı bir şey anlaşıldığı kanıtlanmıştır. Gezi Direnişi mevcut siyasal düzenin "kabul edilebilir" ölçülerine çekilmeye çalışllırken onun çoğulcu yönü tamamen göz ardı edilmiş değildir. Bir araya gelmesi düşünülemez grupların birlikteliğinin görüntüleri 
hâkim demokratik çoğulculuğun sınırlarında yorumlanmıştır. ${ }^{16}$ Ancak Gezi Direnişi’nde kanıtlanan çoğulluk durumu, farklılıkları zaman zaman düşmanlık çizgileriyle belirlenmiş grupların salt bir araya gelişini değil, bu birliktelik içinde kendi görüşlerinin düşünsel sınırlarının yerinden oynamasını da kapsamaktadır. Gezi Direnişı’ne bir milat olma özelliği kazandıran ve tüm siyasal aktörlerin ama özellikle de direnişin bileşenlerinin mevcut konumlarını gözden geçirmeye zorlayan unsur, düşünsel sınırları zorlayan bu çoğulcu deneyimdir. Hangi koşulların bu deneyime izin verdiğinin araştırılması Gezi Direnişi’nin özgün ve şaşırtıcı yönünün anlaşılmasında önemlidir. Bir araya gelen farklılıklar neden başka bir zeminde değil de Gezi Direnişi içerisinde temel yapılarına nüfuz eden çoğulcu bir durumla karşılaşmıştır? Farklı görüşlerin bir araya gelebileceği pek çok zemin varken neden farklı görüşler Gezi Direnişi’nde kendilerine yönelmek durumunda kalmıştır?

Gezi Direnişi’nde eylemci bileşenlerin özgün bir çoğulluk durumu içinde bir arada olmalarını sağlayan çeşitlilik, çoğunlukla hâkim ideoloji dışında kendini ifade etmediği için apolitik olarak adlandırılan ve 1980 ile 2000 yılları arasında doğan kuşağın geleneksel ideolojik bagajlarının bulunmamasıyla açıklanmıştır. ${ }^{17}$ Bu kuşağın, geleneksel muhalefet ve örgütlenme biçimleri ile Türkiye’nin kutuplaşmış ideolojik konumlanmalarına karşı bir duruş sergilediği vurgulanmıştır. Ancak bu kuşak analizi, geleneksel muhalefet ve örgütlenme biçimleri ile mevcut ideolojik kamplaşmaların sorgulanabildiği koşulların neden ve nasıl Gezi Direnişi’nde oluştuğunu açıklayamamaktadır. Gezi Direnişỉnin bileşenlerini kuşak analizi dışında ele aldığımızda, siyasal mücadele sürdürmekte olan feminist hareket, LGBT hareketi gibi toplumsal hareketler ve sol muhalif örgütlerin yanında kendini siyasal bir mücadele etrafında tanımlamayan taraftar toplulukları gibi bileşenlerin varlığına şahit olunmuştur. Hareketi dışarıdan anlamaya çalışan gözler için hoşgörü ve saygı çerçevesindeki bir çoğulculuk tablosu olarak görünen bu çeşitlilik, kendi içinde görüşlerin düşünsel sınırlarının zorlandığı süreçlere girmiştir. Gezi Direnişỉnin özgün çoğulculuk anlayışını hazırlayan ve politikanın deneyimlenmesine olanak sağlayan bu süreçleri çarpışma, şaşırma ve üretme şeklinde adlandırarak ele alacağız.

\section{Çarpışma, Şaşırma ve Üretme}

Birbirini dışlama eğilimde olan görüşlerin bir arada var olabildiği Gezi Direnişi’nde bu karşılaşmalar sorunsuz gerçekleşmemiştir. Eyleme katılan herkes, diğerlerinin yanında bulunmak isteyip istemediğini tartmak durumunda kalmıştır. Yine de eylemlilik süresince özellikle bir grup ya da bir siyasi partinin liderliği hâkim olmamıştır. Böylece farklı görüşler, birbirini dışlama

16 Gezi Direnişi sırasında çekilen bir fotoğrafta BDP bayrağı taşıyan, Türk bayrağı taşıyan ve kurt işareti yapan üç kişi aynı karede yer almıştır. Bir araya gelmesi düşünülemez üç farklı görüşü temsil eden bu kare gerek medyada gerek sosyal medyada bolca paylaşılmış ve tartışılmıştır. Benzer şekilde Gezi Parkı’nda Cuma namazı kılan gruba bazı eylemcilerin güvenlik çemberi oluşturması da Gezi Direnişi’nin farklılıkların birlikteliğini vurgulayan deneyimleri arasına girmiştir. Áncak Gezi Direnişi; farklılıkların sadece bir araya gelmesiyle değil, farklılıkların birlikte değişmesine izin veren karakteriyle özgündür.

17 Gezi Direnişi’ni 1980 ve 2000 yılları arasından doğan ve Y kuşağı olarak adlandırılan kuşağın niteliklerine odaklanarak ele alan birkaç değerlendirme için bkz. Örer (2013), Arman (2013), İnsan Haber (2013). 
eğilimine rağmen birbirleriyle büyük sorunlar yaşamadan direnişin parçası olmuşlardır. Elbette bu bir arada olma sürecinde siyasal iktidarın otoriter tavrı ve polis şiddetinin ortaklaştırıcı etkisi bulunmaktadır. Ancak dış etkilerden nispeten bağımsız, eylemlilik içinde gerçekleşen ve adına çarpışma diyeceğimiz bir sürecin de bu birliktelikte azımsanmayacak bir etkisi vardır. Farklı görüşlerin dile getirildiği Gezi Direnişi sürecini, bu farklılıkların bir karşılaşması ya da teması olarak görmek de mümkündür. Ancak bu sürecin karşılaşma ya da temas yerine çarpışma olarak nitelenmesinin nedeni durumun daha çok bir kazayı andırıyor olmasıdır. Gezi Direnişìnde farklı görüşlerin, farklı flamaların, farklı sloganların, eylemcilerin de beklemediği bir şekilde çarpışmaları söz konusudur. Cinsiyetçi sloganlarla feministlerin ve LGBT'lerin, "Mustafa Kemal'in askerleriyiz" sloganıyla "kimsenin askeri değiliz" sloganının, "örgüt değil halkız" diyenlerle sol örgütlerin ve daha nicelerinin birbiriyle çarpıştığı bir kaza alanıdır Gezi Direnişi.

Eylemcilerin birbiriyle yaşadıkları bu kaza etkisinin ardından bir şaşkınlık süreci doğmuştur. $\mathrm{Bu}$ şaşkınlığın nedeni, bir tarafın diğer tarafın varlığından daha önce haberdar olmaması ya da daha önce onunla hiç karşılaşmamış olması değildir. Şaşkınlık, mücadele ve eylemlilik içinde bir arada olmaktan kaynaklanmaktadır. Ne feministler ve LGBT’ler ilk kez cinsiyetçi bir tutumla karşı karşıya kalmışıır, ne de militarizm karşıtları ilk kez militarist bir söylemle. Gezi Direnişi’nin öngörülemeyen, kendiliğinden gelişen seyrinin karşısındakilerde yarattığı şaşkınlığa daha önce değinilmişti. Ancak eylemcilerin kendilerinin de bu şaşkınlıktan payını aldığını belirtmek gerekir.

Eylemlilik içinde yaşanan bu şaşkınlık yerini bir yanıt arayışına bırakmıştır. Bu yanıt arayışı da düşünsel sınırları sınayan bir üretim süreci doğurmuştur. Toplumsal cinsiyet farkındalığıcinsiyetçilik örneğiyle açıklayacak olursak feministler, eylemlilik içinde yüz yüze geldikleri cinsiyetçi sloganlar karşısında acil bir yanıt üretmek durumunda kalmıştır. Cinsiyetçi sloganlara "küfürle değil inatla diren" sloganıyla karşı çıkılmıştır. Bir yandan siyasal iktidara "ellerini bedenimden çek" denirken diğer yandan eylemlilik içindeki ataerkil ve cinsiyetçi söylemlerle mücadele edilmiştir. Mücadelenin içerideki boyutunda düşünsel sınırlar iki taraflı olarak sarsılmıştır. Bir yanda cinsiyetçi küfürlerle slogan atanlar ilk kez bundan rahatsızlık duyanlarla, bu rahatsızlığın nedenlerinin de açıklanabildiği bir zeminde çarpışmış ve böylece öfkeden doğan sıradan ve masum bir tepki gibi hiç sorgulanmadan sarf edilen sözlerin cinsiyetçi içeriğini düşünmek zorunda kalmışlardır. Çünkü bu uyarı, kavga anında düşman tarafından değil, ortak mücadelenin diğer bileşenleri tarafından dile getirilmişstir. Öte yandan toplumsal cinsiyet üzerine bilgi üretme ve paylaşma mücadelesinde olan feminist hareket, direniş esnasında karşı karşıya kaldığı cinsiyetçi duruma yanıtını yine direniş içinde üretmiştir.

Feminist hareket örneğinde olduğu gibi kendi düşünsel ve fiziki sınırları içinde mücadele yürüten hareketler Gezi Direnişi’nde uzun zamandır ulaşamadıkları bir paylaşım ve üretim deneyimine sahip olmuştur. Elbette günlük hayatta farklıgörüşler her an birbiriylekarşılaşmaktadır. Ancak bu karşılaşmalarda tarafların konumları Gezi Direnişi’nde olduğu gibi mücadele esnasında ortaklık içinde belirlenmemiştir. Farklı görüşlerin rutinin içinde gerçekleşen karşılaşmasında ya temastan kaçınılır ya da temas düşmanca gerçekleşir. Oysa Gezi Direnişi’nde dost-düşman ayrımı, mücadele içi ve dışı ayrımıyla şekillenmiştir. Uzlaşı düzeninde birbirine düşman olanlar ya da birbirini hiç tanımayanlar Gezi Direnişỉnde dost olmuş, ancak bu birbirlerine karşı yanıtlar 
üretmelerine engel olmamıştır. Direnişin forumlarda sürdürülen kısmında da üretilen yanıtlar ve edinilen pratiklerin varl lğı hâkim olmuştur. Böylelikle forumlarda, edinilen politik deneyimin sürekliliği sağlanmaya çalışılmıştır.

Gezi Direnişi’nde çarpışma, şaşırma ve üretme süreçlerini hazırlayan özgün çoğulluk durumunun politikaya dair verdiği ipuçlarını Rancière ve Arendt'in kavramları ışığında arayabiliriz. Öncelikle Gezi Direnişi, Rancière'in (1995: 53) politik eylemi tarif ederken belirttiği gibi; görünmez olanı görünür kılan, gürültü olanı söz olarak duyuran eylemlere sahne olmuştur. Politik eylem, iktidar sahibi olanlar ve olmayanların konumlarını yerinden oynatırken, bu eşitsiz konumların doğal olduğu fikrini de tartışmaya açar (Rancière, 1995: 143). Gezi Direnişi, hem siyasal iktidar ve ona maruz kalanların konumlarının sorgulandığı, hem de eylemci bileșenlerin birbirlerine karşı konumlarını tartmalarına olanak sağlayan, politikanın gerçekleştiği bir sürece damgasını vurmuştur.

Gezi Direnişi’nin kanıtladığ ç̧oğulluk durumu, son derece özgün ve nadiren deneyimlenebilen bir toplumsal ilişki biçiminin de ipuçlarını vermiştir. Rancière’in de (1995: 60) belirttiği gibi, eylemci bileşenler elbette yoktan var olan özneler değildir. Ancak politik eylem, belirlenmiş ve doğallaştırılmış kimlikleri aşan bir özneleşme (subjectivation) sürecinde gerçekleşir (Rancière, 1995: 60). Eylemci bileşenlerin hiçbiri direniş sürecinde değişime uğramaktan, kendini, görüşlerini ve düşünsel sınırlarını sorgulamaktan kaçamamıştır. Böylece Gezi Direnişi, özneleşme diyebileceğimiz bir toplumsallığa kapı aralamıştır. Bu özgün kolektif varoluş hali Hannah Arendt'in (1998: 123) birlikte ve uyum içinde eylemek (acting together and in concert) olarak adlandırdığı durumu da doğrular niteliktedir. Her ne kadar Gezi Direniş̧innin parçası olan bileşenlerin birbirileriyle uyumlu olmaktan çok çatışmalı bir ilişkileri olsa da, birlikte ve uyum içinde eyleme ifadesi, rutin bir karşılaşmaya göre çok daha fazla yakınlaşarak ortak bir mücadelenin günlerce sürdürüldüğünü vurgulamak açısından önemlidir.

Gezi Direnişi’nin politikaya dair sunduğu bir başka ipucu, Rancière ve Arendt'in farklı şekillerde vurguladığı gibi politik eylem sürecinin, kesin bir öngörülemezlik ve belirsizlikle yüklü oluşudur. Politika içinden ne çıkacağı belli olmayan süreçlere gebedir. Arendt bu nedenle politikayı insanın üç temel aktivitesi olarak sıraladığ emek, iş ve eylem kategorilerden sadece sonuncusuyla ilişkilendirir. ${ }^{18}$ Çünkü sadece eylem, zorunluluk alanı dışında gerçekleştiğinden belirsiz, kendiliğinden ve öngörülemez niteliktedir (Arendt, 1998: 233). Rancière ise (2007: 23-40) polis süreci ve belirsizlik ilişkisini; belirlenmemişlik, tanımlanmamışlık ve sınırsızlık anlamlarına gelen apeïron (sınırları olmayan) kavramıyla açılar. Polis; apeïron'u ölçmek, sınırlandırmak, yerini belirlemek sanatının düzenidir (Rancière, 2007: 29-35). Eğer politika, polis düzeninin belirlediği konumlar, ilişkiler ve kimliklerin dışına çıkarak gerçekleştirilen eylemlerle mümkünse, politik eylem ölçü ve sınırları yıkan süreçler meydana getirir. Siyasal iktidarlar açısından Gezi Direnişi gibi toplumsal mücadelelerin en tehlikeli yönü şüphesiz, uzlaşma mantı̆̆ içinde süregiden toplumsal konumların, eşitsizliklerin ve tahakküm ilişkilerinin, içinden ne çıkacağı ve ne yöne gideceği belirsiz bir süreçte kırılmaya uğradığı politik yönüdür.

18 Arendt'in, insanoğlunun dünya üzerindeki etkinliğini ifade eden vita activayı emek, iş ve eylem kategorileri altında incelediği eseri için bkz. Arendt (1998). 
Gezi Direnişi̧ni bastırmaya yönelik girişimlerde, direniş öncelikle politikanın neden olduğu belirsizlik durumundan koparılmaya çalışılmıştır. Farklılıkların birbiriyle çarpışması sonucu yerinden oynayan düşünsel sınırlar, sürekli bir üretimin gerçekleştiği özgün bir çoğulluk durumunu mümkün kılmıştır. Politikanın parmaklarımızın ucuna dokunduğu Gezi Direnişi süreci, karşısındakileri olduğu kadar kendi kendini de şaşırtan çarpışmalar, yanıt arayışları ve üretilen yanttlarla var olmuştur. Direnişe özgü olduğunu ve net şekilde tarif edilemediğini açıklarcasına sıkça "Gezi Ruhu” şeklinde adlandırılan olgu, üretime açık bir çoğulluk durumundan doğan politika deneyimidir. Gezi Direnişi’nde politik olan, siyasal iktidara iletilmek üzere belli başlıklar altında taleplerin dile getirilişi ya da siyasal iktidarla müzakere masasına oturulması değil, çarpışma, şaşırma ve üretimin damgasını vurduğu kolektif mücadele sürecidir.

\section{Sonuç Yerine}

Gezi Direnişi, yirmi birinci yüzyılın başında gerçekleşen özgün bir toplumsal mücadele olarak muhalefet edenler ve siyasal iktidarlar kadar sosyal bilimcilerin de ilgisini uzun yıllar boyunca üzerine çekecek bir saha oluşturmaktadır. Gezi Direnişìnde ve tüm toplumsal hareketlerde sosyolojik analiz mücadelenin nerede, ne zaman, hangi koşullar altında, kimler tarafından ve ne tür eylem biçimleriyle gerçekleştiğini araştırarak olgusal gerçekliği aydınlatır. Ancak böyle bir analiz, hareketi yarattığı somut etkilerle ölçerken onun taşıdığı dönüştürücü potansiyeli ve alternatif bir toplumsal ilişki arayışını göz ardı etmemelidir. Toplumsal hareketler araştırmaları olgusal gerçekliği aydınlatmanın yanında mücadelelerin politik boyutunu açığa çıkartabileceğimiz araçlar da sağlayabilir. Bir toplumsal hareketin politik boyutu; nerede, ne zaman, hangi koşullar altında, kimler tarafından ve ne tür eylem biçimleriyle gerçekleştirilmiş olursa olsun, o mücadelenin dönüştürücü potansiyeli ve arayışlarıyla ilgilidir. Toplumsal hareketler, mevcut eşitsizlikler ve tahakküm ilişkilerine karşı mücadele zemini yaratırken başka türlü bir toplumsal ilişkinin de mümkün olduğunu gösteren politika deneyimleriyle de ele alınmayı hak etmektedir.

Bu bağlamda Gezi Direnişìni salt dile getirilen taleplerle açıklamak, bu mücadelenin politik boyutunu görünmez kılar. Keza gücünü karşısındakileri şaşırtmasından ve öngörülemez karakterinden alan direnişin siyasal iktidar tarafından tanımlanmasıyla, bu sınırsız devinimi belli bir yöne kanalize etmek ve onu doğduğu yer olan Gezi Parkı̉na hapsetmek amaçlanmıştır. İktidarsız bir politik zeminde, hâkim düzen tarafından belirlenmiş tüm ilişki biçimleriyle kırılma yaratan bir toplumsallık durumu karşısında siyasal iktidar, hiyerarşik konumları yeniden üretecek mekanizmalara başvurmuştur. Siyasal iktidar Gezi Direnişi’ni, ancak çevre hassasiyeti ve katılımcı yerel yönetim talebi çerçevesinde tanımıştır. Oysa Gezi Direnişi, siyasal iktidarın kendi algı çerçevesine sıkıştırdığının ötesinde çok özgün bir çoğulluk durumunun zemini olmuştur. Öyle ki bu çoğulluk durumunda mücadele deneyimi ve anlayışları bambaşka olan bileşenler, rutinin dışında bir araya gelip yan yana mücadele etmiştir. Bu süreçte farklı anlayışlar birbiriyle çarpışmış, gördüklerine şaşırmış ve kendi düşünsel sınırlarını zorlayan bir politik üretim mümkün olmuştur. 
Gezi Direnişi böylece toplumsal mücadeleler tarihinde sorgulayıcı, üretici ve dönüştürücü karakteriyle önemli bir deneyim olarak yerini alırken mevcut siyasal mekanizmaların dışında bir politika anlayışının da ipuçlarını vermiştir. Elbette biz politikayı, Gezi Parkı Direnişi’nde olduğu gibi ve Rancière'in tarifine uygun olarak ancak ardından "normale” dönülen kısa süreli özgürleşme mücadelelerinde görebildik. Çünkü tahakküm ilişkileriyle ve eşitsizliklerle malul toplumumuzda, isyan ve direniş anlarından başka politikanın toplumsal olarak daha görünür olabileceği bir zemine sahip değiliz. Arendt’in düşündürdüğü şekilde politikayı insanın kolektif varoluşunun ve eyleminin bir biçimi olarak yaşatabilecek mekanizmalardan mahrumuz. Yine de bu eksiklik, politikayı bugüne özgü mücadelemizin aracı olarak sahiplenirken, onun gelecek tahayyülümüzle ilişkisini kurmaya engel değildir. Eğer politika bugün eşitsizliklerden özgürleşme mücadelemizin yoluysa, kendisinden özgürleşeceğimiz eşitsizliklerin yeniden üretilmemesi için sürekli bir mücadelenin yolu olarak da düşünülebilir. Hem Rancière'deki gibi eşitsizlikler karşısında eşitliği kanıtlayan hem de Arendt'deki gibi kolektif varoluşumuzun ve eylemimizin bir biçimi olarak sürekliliğe sahip bir politikanın mümkün olup olmadığını ancak Gezi Direnişi gibi toplumsal mücadelelerin politik boyutunu görünür kılıp onu daha çok deneyimleyerek keşfetmemiz mümkündür. 


\section{Kaynakça}

Anadolu Ajansı (2013) “Kimsenin Gerilimi arttırmaya Hakkı Yok” [çevrimiçi], 1 Haziran, http://www. aa.com.tr/tr/politika/188759--kimsenin-gerilimi-artirmaya-hakki-yok [Erişim 23.12.2013].

Arendt, H. (1990 [1963]) On Revolution, London: Penguin Books.

Arendt, H. (1998 [1958]) The Humain Condition, Chicago: The University of Chicago Press.

Arman, A. (2013) "Yaşasın Y Kuşağı" [çevrimiçi], Hürriyet, 09 Haziran, http://www.hurriyet.com.tr/ yazarlar/23465715.asp [Erişim, 28.11,2013]

BBC (2013) “Taksim Platformu’nun Taleplerini İçeren Tam Metin” [çevrimiçi], BBC Türkçe Servisi, 5 Haziran, http://www.bbc.co.uk/turkce/haberler/2013/06/130605_taksim_platformu_talepler.shtml [Erişim, 06.06.2013].

Beetham, D. (1994) “Liberal democracy and the limits of democratization", David Held (der.), Prospects for Democracy içinde, Oxford: Polity Press.

Benlisoy, F. (2013) Gezi Direnişi: Türkiye’nin Enteresan Başlangıcı, İstanbul: Agora Kitaplığı.

Berktay, F. (2012) Dünyayı Bugünde Sevmek: Hannah Arendt’in Politika Anlayışı, İstanbul: Metis Yayınları.

Çetinkaya, Y. D. (2008) “Tarih ve Kuram Arasında Toplumsal Hareketler”, Y. Doğan Çetinkaya (der.), Toplumsal Hareketler: Tarih, Teori ve Deneyim içinde, İstanbul: İletişim Yayınları, 15-61.

Easton, D. (1965) A Systems Analysis of Political Life, New York: Wiley.

Gambetti, Z. (2009) "İktidarın Dönüşen Çehresi: Neoliberalizm, Şiddet ve Kurumsal Siyasetin Tasfiyesi”, İ.Ü. Siyasal Bilgiler Fakültesi Dergisi, 40: 145-166.

Inglehart, R. (1977) The Silent Revolution: Changing Values and Political Styles, Princeton, Princeton University Press.

İnsan Haber (2013) “90 Kuşağından Çok Samimi Gezi Süreci” [çevrimiçi], 19 Ağustos, http://www.insanhaber. com/insan-ozel/90-kusagindan-cok-samimi-gezi-sureci-h20120.html [Erişim, 28.11,2013].

Jasper, J. M. (2002 [1997]) Ahlaki Protesto Sanatı: Toplumsal Hareketlerde Kültür, Biyografi ve Yaratıcılı, [The Art of Moral Protest: Culture, Biography, and Creativity in Social Movements], çev. Senem Öner İstanbul: Ayrıntı Yayınları.

Le Bon, G. (1971 [1895]) Psychologie des foules, Paris, Les Presses Universitaires de France.

Martin, W. G. (2008), “Giriş: Sistem Karşıtı Hareket Arayışı”, W. G. Martin (der.), Toplumsal Hareketler 17502005: Dipten Gelen Dalgalar [Making Waves. Worldwide Social Movements 1750-2005] içinde, çev. Deniz Keskin, İstanbul: Versus Kitap, 5-19.

McCarthy J. D. ve M. N. Zald (1977), "Resource Mobilization and Social Movements: A Partial Theory", American Journal of Sociology, Volume: 82(6):1212-1241.

Olson, M. (1971) The Logic of Collective Action: Public Goods and the Theory of Groups, Cambridge: Harvard University Press.

Örer, A. (2013) "Y Kuşağının Z Raporu” [çevrimiçi], Radikal Hayat, 21 Temmuz, http://www.radikal.com. tr/hayat/y_kusaginin_z_raporu-1142677 [Erişim, 28.11,2013]

Rancière, J. (1992) "Politics, Identification, and Subjectivization", October, The Identity in Question, 61: 58-64.

Rancière, J. (1995) La Mésentente: Politique et Philosophie, Paris: Édition Galilée.

Rancière, J. (2007 [1998]) Siyasalın Kıyısında [Aux Bord du Politique], çev. A. U. Kılıç, İstanbul: Metis Yayınları.

Rancière, J. (2012 [1981]) La Nuit des Proletaires. Archives du Rêve Ouvrier, Paris: Édition Pluriel. 
Sabah (2013) “Topbaş’tan Gezi Açılaması” [çevrimiçi], http://www.sabah.com.tr/Gundem/2013/06/08/ topbastan-gezi-parki-aciklamasi (Erişim, 11.12.2013)

T24 (2013) “Gezi Parkı Direnişçileriyel Yapılan Anketten Çıkan Sonuçlar...” [çevrimiçi], 4 Haziran, http:// t24.com.tr/haber/gezi-parki-direniscileriyle-yapilan-anketten-cikan-ilginc-sonuclar,231335.

Therborn, G. (1989) Sermayenin Egemenliği ve Demokrasinin Doğuşu, çev. Ş. Tekeli, Ankara: Verso Yayınları. Tilly, C. (1978) From Mobilization to Revolution, New York: McGraw-Hill.

Tilly, C. (1986) The Contentious French, Cambridge: Belknap Press.

Touraine, A. (1978) La Voix et le Regard, Paris: Éditions du Seuil.

Yazmac1, Ü. (2013) "Basitleştirmek, İfşa Etmek, Gizemini Çözmek: Pierre André Taguieff ve Seküler Zamanlarda Antisemit Komplocu Tahayyül”, Marmara Üniversitesi Siyasal Bilimler Dergisi, 1(1): 153-180. 